Çiftçi, Ö. ve Uzunyol, C. (2019). Öğretmen görüşlerine göre Türkçe öğretiminde karşılaşılan problemlerin kaynakları. Ana Dili Eğitimi Dergisi, 7(4), 825-840.

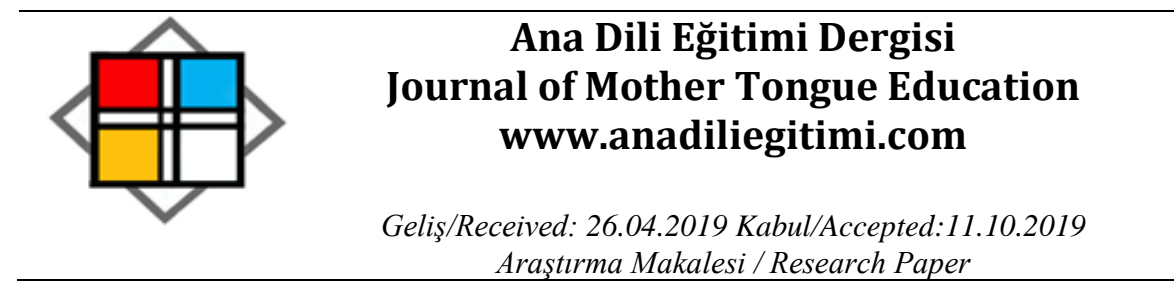

\title{
Öğretmen Görüşlerine Göre Türkçe Öğretiminde Karşılaşılan Problemlerin Kaynakları *
}

\author{
Ömer ÇiFTÇi ${ }^{* *}$ \\ Celal UZUNYOL ${ }^{* * *}$
}

\begin{abstract}
Öz
Dili öğrenmede karşılaşılan birçok problem vardır. Bu çalışmamızın amacı da Türkçe öğretiminde karşılaşılan başıca problemleri ve bu problemlerin kaynaklarını ortaya koymaktır. Araştırmanın çalışma grubunu Van'ın İpekyolu, Tuşba ve Edremit ilçelerindeki 3 okuldan seçilmiş 10 öğretmen oluşturmaktadır. Nitel araştırma yaklaşımına göre tasarlanan çalışmada iç içe geçmiş durum çalışması modeli kullanılmışır. Veri toplama aracı olarak araştırmacılar tarafından geliştirilen "Yarı Yapılandırıımış Görüşme Formu" kullanılmıştır. Yarı yapılandırıımış görüşme formundaki sorular hazırlanırken uzman görüşlerine başvurulmuştur. Öğretmenlerle yapılan görüşmede öğretmenlerin verdikleri cevaplar kayda alınmıştır. Verilerin analizi nitel veri çözümleme tekniklerine göre yapılmıştır. Öğretmenlerin ses kayıtları yazıya döküldükten sonra belirlenen temalar çerçevesinde irdelenmiştir. Elde edilen bulgulara göre programın uygulanması için uygun ortamların olmadığı ve ders kitaplarındaki metinlerin öğrencilerin seviyesine uygun olmadığ saptanmıştır. Bu durumların çocuğun, dil becerilerini edinmesinde olumsuzluklara sebep olduğu, ayrıca çocuğun çevresinin de (aile, arkadaş, okul) çocuğun dil ediniminde önemli bir role sahip olduğu saptanmıştır.
\end{abstract}

Anahtar Kelimeler: Türkçenin öğretimi, Türkçenin öğretiminde karşılaşılan problemler

\section{Sources of Problems in Teaching Turkish Based on Teacher Opinions}

\begin{abstract}
There are numerous problems in language learning. The aim of this study was to identify the main problems and their sources in the process. The study group consisted of 10 teachers from 3 schools in the İpekyolu, Tuşba and Edremit districts of the Van province. In the study designed in the qualitative research tradition, the nested case study model was used. A "semi-structured interview form" developed by the researchers was used as the data collection tool. In preparing the questions in the semi-structured interview form, expert opinions were sought. Teachers' answers were recorded during the interviews. The data were analyzed using qualitative data analysis techniques. The recorded interviews were analyzed and the emerging themes were determined. Based on the findings, it was found that there were no suitable environments for the implementation of the program and the texts in the course books were not suitable for the students' level. It was determined that those circumstances caused negativity in the acquisition of the language skills by the children and also the environment (family, friend, school) had an important role in the language acquisition of the children.
\end{abstract}

Keywords: Teaching Turkish, Problems in teaching Turkish

\footnotetext{
* Çalışma 4-5 Ekim 2017'de 10. Uluslararası Türkçenin Eğitimi ve Öğretimi Kurultayı'nda sözlü bildiri olarak sunulmuştur.

** Doç. Dr., Yüzüncü Yıl Üniversitesi, Eğitim Fakültesi, Türkçe Eğitimi ABD, Van, omerciftci@yyu.edu.tr ORCID: 0000-0001-6875-1124.

*** Öğretmen, Yüksek Lisans Öğrencisi, celaluzunyol65@hotmail.com, ORCID: 0000-0003-0021-0609
} 


\section{Giriş}

Dilin insan hayatındaki önemi tartışılmazdır. İnsan olmanın yegâne özelliklerinden olan ve insanları bir araya getirip toplum kavramını ortaya çıkaran, dil gerçekliğidir. Anne karnında başlayan, sosyal çevre ve okullaşmayla birlikte bireyin zihninde sistemli bir yapıya dönüşen dil, insan olmanın en önemli hususlarındandır. Gemalmaz (2010)'a göre dinamik sistemler arasındaki her türlü iletişimi ve denetimi sağlayan durağan/biçimsel dizgelere, türüne ve düzeyine bakmaksızın en geniş anlamıyla dil denilmektedir. Göçer ve Moğul (2011) dili, insanların yaşamını düzenleyen; onları bir arada tutarak milletleşme çizgisine taşıyan; düşünmeyi, anlamlandırmayı ve anlamlandırılanın aktarılmasını sağlayan bir olgu olarak tanımlamaktadırlar. İnsanların millileşme çizgisine ulaşmaları ancak kuşaktan kuşağa aktarılan kültür yardımıyla gerçekleşmektedir ki kültürü kuşaklara aktaran da ana dildir.

Ana dili edinimi erken yaşlarda başlar. Alyılmaz (2010)'a göre dil edinimi okul öncesinde çocuğun yakın çevresiyle olan kişilerle, ailesiyle etkileşimi sonucunda başlar. Dilin etkili ve doğru kullanımıyla okuma yazma becerisinin öğrenimi ve gelişimi sistemli bir çalışma gerektirdiği için okulda ya da başka bir eğitim kurumunda öğretilmeyi gerekli kılar. Bu durum da dil eğitimini önemli hâle getirmektedir. Çocukta okullaşmayla birlikte bilinçli dil edinim süreci de başlar. Bu bilincin kazandırıldığı ve işlevselliğe dönüştürüldüğü ana ders de Türkçe dersidir. Bilgi, beceri ve davranışların kazanılmasını etkileyen Türkçe eğitiminin temel amacı, kültürün taşıyıcı ögesi konumunda olan ana dili becerilerini iyi ve doğru kullanan bireyler yetiştirmektir (Özbay, 2003: 67).

Böylesi bir misyona sahi olan dilin özenli bir biçimde edindirilesi şarttır. Fakat gerek yurt içinde gerek yurt dışında çeşitli kurumlarca gerçekleştirilen Türkçe öğretimi faaliyetlerinde birtakım sorunlarla karşılaşılmaktadır. Bu sorunlar alan yazında yapılan farklı çalışmalarda sürekli karşımıza çıkmaktadır. Alyılmaz (2010: 729)'a göre Türkiye'de ilköğretimden yükseköğretimin sonlarına kadar ana dili olarak Türkçe eğitimi yapılsa da öğrencilerin ana dili kullanımlarında sorunlar yaşadığı ve Türkçeyi verimli kullanamadığı bir gerçektir.

Türkçe öğretiminde kullanılan yöntem ve materyallerin çağın koşullarına uygun olmayışı ve eksikliklerinin bulunması da önemli sorunların kaynağı durumundadır" (Er, Biçer ve Bozkırlı, 2012: 52). Bu materyallere ilave olarak kullanılan başka bir materyal de ders kitaplarıdır. Ders kitapları hem eğitim hem de öğretim amacıyla kullanılan temel kaynaklardır. Ders kitapları öğrencinin yaş ve bilgi seviyesine uygun bilişsel ve duyuşsal becerilerle donatılmış zengin metinlerden oluşan, öğretim programlarının esas aldığı ilkeler doğrultusunda hazırlanan, ihtiva ettiği bilgileri öğrenciye aktaran basılı eğitim ve öğretim materyalleridir (Çeçen ve Çiftçi, 2007: 1). Ders kitapları tüm dünyada en geniş kullanıma sahip basılı ürünlerdir. Ayrıca, ders kitapları eğitim sürecinde bilgi edinmenin temel aracıdır ve kullanımı oldukça kolaydır (Güneş, 2002: 2). Temel okuma-yazma öğrenilirken öğrencilerin karşılaştıkları kitaplar ve metinler, onların ileriki dönemlerde okuma alışkanlığını edinmiş okurlar 
olarak karşımıza çıkmasında önemli bir rol oynarlar. Bu nedenle Türkçe derslerinde kullanılan materyallerin en başında yer alan ders kitaplarında bulunan metinler öğrencilerin düzeyine uygun olarak hazırlanmalıdır (Sever, 2003: 17). Dil, bireyin bilgi edinimi, edinilen bilgileri aktarımı açısından önemlidir. Bu nedenle bireyin ana diline hâkim olması gerekir. Ana dilini öğrenme sürecinde materyal örgütlenişi önemlidir. Başarıya ulaşmak isteyen eğitimciler materyal örgütlenişini sağlamalıdır. Kullanılan metinler çocuğun ihtiyaçlarına uygun olmalı, ilgilerinde sürekliliği sağlamalıdır.

Temelde iyi vatandaş yetiştirmeyi amaçlayan ilköğretim kurumlarında yaşanan sorunları belirleyerek çözüm yollarını araştırmak, eğitim bilimciler için önemli bir görev olarak karşımıza çıkmaktadır (Güneş ve Kara, 2016: 143). Okullarda Türkçe öğretimi sürecinde yaşanan problemlere ilişkin gözlemlere dayanılarak şunlar söylenebilir: Problemin çıkış kaynağına baktığımızda müfredatı, ders ve çalışma kitaplarını, aileyi, öğrenciyi, öğrencinin sosyal çevresini, okulu ve okulun paydaşlarını görmemiz mümkündür. Sayılan bütün bu etkenler, alan yazında yapılan benzer çalışmaların (Çiftçi ve Bulut, 2018; Susar Kırmızı vd. 2016; Adıgüzel, 2009; Demirtaş vd. 2007; Dağlı ve Han 2017 vs.) hemen hemen tamamında birer sorun olarak dile getirilmiştir. Bu çalışmayla da var olan durum detaylarıyla ortaya konulmaya çalışılmıştır. Çalışmanın problem cümlesi, "Van ili merkez ilçelerinde görev yapan Türkçe öğretmenlerinin görüşlerine göre dil becerilerinin öğretilmesinde karşılaşılan problemlerin kaynakları nelerdir?" Şeklinde oluşturulmuştur. Çalışmanın alt problemleri ise şunlardır:

Dil becerilerinin öğretilmesinde;

1. Türkçe ders kitabından kaynaklanan problemler nelerdir?

2. Öğrencinin ailesinden kaynaklanan problemler nelerdir?

3. Okuldan kaynaklanan problemler nelerdir?

4. Diğer öğretim materyallerinden kaynaklanan problemler nelerdir?

5. Türkçe öğretimi programından kaynaklanan problemler nelerdir?

6. Öğrencinin arkadaş çevresinden kaynaklanan problemler nelerdir?

7. Öğrencinin ilgi, ihtiyaç, yetenek ve tutumundan kaynaklanan problemler nelerdir?

\section{Yöntem}

\section{Araştırmanın Modeli}

Türkçe öğretiminde karşılaşılan problemlerin kaynağını ortaya koymayı amaçlayan bu çalışmada, durum çalışması desenlerinden birisi olan iç içe geçmiş tek durum deseni kullanılmıştır. "iç̧ içe geçmiş tek durum deseninde, tek bir durum içinde çoğu kez birden fazla alt tabaka veya birim olabilmektedir (Yıldırım ve Şimşek, 2008)." Türkçe öğretiminde etkili olan aile, okul, çevre, eğitim ortamları ve programın analiz birimi olması, durumun iç içe geçmişliğini göstermektedir. Araştırmada 
bu durum içinde yer alan alt analiz birimlerinin iç içe geçmiş yapısının, derinlemesine incelenmesinin araştırma durumunu ayrıntılı olarak açıklayacağı düşünülmektedir.

\section{Araştırma Grubu}

Araştırmanın katılımcıları Van'ın İpekyolu, Tuşba ve Edremit ilçelerindeki üçer okuldan toplam 9 okulda, en az 5 yıl görev yapmış 10 Türkçe öğretmeninden oluşmaktadır. Öğretmenler seçilirken cinsiyet dengesi gözetilmemiş, öğretmenlerin en az beş yıllık öğretmen olmaları ve çalışmaya gönüllü katılmaları dışında herhangi bir ölçüt aranmamıştır. Katılımcıların 8'i erkek, 2'si ise kadındır. Görüşme türlerini ele alan ilgili literatürde yarı yapılandırılmış görüşmelerin gerçekleştirildiği çalışmalardaki çalışma grubu için alt ve üst bir sınır belirtilmemektedir. Alan yazında yarı yapılandırılmış görüşmenin gerçekleştirildiği benzer çalışmalarda çalışma grubu 15 (Gün, 2012) ile 40 (Uygun ve Katrancı, 2013) kişi arasında değişmektedir. Çalışmada analiz biriminin fazla olması ve birimlerin derinlemesine incelenmesi göz önüne alındığında on öğretmen yeterli görülmüştür.

\section{Veri Toplama Araçları}

Veriler 2016-2017 eğitim öğretim yılında toplanmıştır. Verilerin toplanması için araştırmacılar tarafından geliştirilen yarı yapılandırılmış görüşme formu kullanılmıştır. Başlangıçta 10 maddeden oluşan görüşme formu bir ölçme değerlendirme uzmanı ve dört Türkçe Eğitimi alan uzmanının görüşleri doğrultusunda en fazla puan alan maddelere göre yeniden düzenlenmiş ve 10 maddeden 7 maddeye indirgenmiştir. Öğretmenlerin görüşme esnasında hakkında fikir beyan ettikleri öğretim programı ve ders kitapları, beşinci sınıfın ortaokula dâhil edilmesinden sonra güncellenen 2006 Türkçe Öğretimi Programı ve bu programa uygun olarak hazırlanan Türkçe ders kitaplarıdır.

\section{Verilerin Toplanması ve Analizi}

Verilerin toplanması için, hazırlanan yarı yapılandırılmış görüşme formu kullanılmıştır. Öğretmenler ile yapılan görüşmeler, öğretmenlerin görev yaptıkları okullarda gerçekleştirilmiştir. Yapılan görüşmeler ses kayıt cihazı ile kaydedilmiştir. Görüşmeler tamamlandıktan sonra iki araştırmacı tarafından ayrı ayrı kayıtların dökümü yapılmıştır. Yarı yapılandırıımış görüşmelerden elde edilen veriler "betimsel analiz" tekniği ile analiz edilmiştir. Bu yaklaşıma göre elde edilen veriler önceden belirlenen temalara göre özetlenir ve yorumlanır. Veriler, araştırma sorularının ortaya koyduğu temalara göre düzenlenebileceği gibi, görüşme ve gözlem süreçlerinde kullanılan sorular ya da boyutlar dikkate alınarak da sunulabilir. Betimsel analizde, görüşülen ya da gözlenen bireylerin görüşlerini çarpıcı bir biçimde yansıtmak amacıyla doğrudan alıntılara sık sık yer verilir (Yıldırım ve Şimşek, 2011: 224). Elde edilen verilerin analizi sürecinde öncelikle araştırma kapsamında belirlenen programdan, öğrencilerden, öğrenme-öğretme sürecinden ve araç gereçlerden kaynaklanan sorunlar ana temalarına yönelik olarak alt temalar oluşturulmuş ve öğretmenlerin görüşlerine yer verilmiştir. 


\section{Bulgular}

Bu bölümde, elde edilen nicel veriler sonucunda Türkçe öğretmenlerinin görüşüne göre dil becerilerinin öğretilmesinde karşılaşılan problemlerle ilgili elde edilen nitel bulgu ve yorumlara yer verilmiştir.

Tablo 1. Türkçe ders kitaplarından kaynaklanan problemler

\begin{tabular}{|c|c|c|}
\hline Tema & Alt Tema & Kodlar \\
\hline \multirow[t]{3}{*}{$\begin{array}{l}\text { Türkçe ders } \\
\text { kitabından } \\
\text { kaynaklanan } \\
\text { problemler }\end{array}$} & Metinler & $\begin{array}{l}\text { Metinler tekdüze, kuru, çocuğun ilgisini çekmekten yoksundur (Ö1; Ö6). } \\
\text { Öğretmenler kendi önceliğine göre farklı metinler kullanabilirler ama bu } \\
\text { konuda yetersizdirler (Ö1). Metinler öğrenciyi düşündürmeye sevk etmiyor. } \\
\text { Çünkü bazı metinlerin verecek bir mesajı bile yoktur (Ö1; Ö2; Ö3; Ö4). Metinler } \\
\text { bölgesel farklılıkları dikkate almıyor. Ders kitapları, okutulacak bölgelere göre } \\
\text { hazırlanmalı (Ö1; Ö2; Ö3; Ö5). Seçicilik çok az. Çok güzel metinlerin yanında } \\
\text { kalitesiz metinler de var (Ö1; Ö2; Ö3; Ö4). Edebiyatımızda şiir de dâhil olmak } \\
\text { üzere çok güzel parçalar vardır. Ne yazık ki bunları kitaplarda göremiyoruz } \\
\text { (Ö4). Çocuğa okuma sevgisini ve dil becerilerini kazandıracak parçaların sayıı } \\
\text { azdır (Ö1; Ö2; Ö3; Ö4). Parçalar öğrencinin duyusal ve zihinsel seviyelerine } \\
\text { uygun değildir (Ö1; Ö2; Ö3; Ö5; Ö6). }\end{array}$ \\
\hline & Kelimeler & $\begin{array}{l}\text { Öğrencilerin, anlamını bilmediği kelime sayısı oldukça fazladır. Buna bağlı } \\
\text { olarak metinlerin zorluk seviyesi artmakta ve öğrencilerin metinleri anlamaları } \\
\text { zorlaşmaktadır. Öğrencinin, hayatı boyunca kullanmaya gerek duymayacağı } \\
\text { arkaik/Osmanlıca sözcükler metinlerde yer almaktadır (Ö1;Ö2;Ö3;Ö5). } \\
\text { Metinlerde soyut anlamlı ve mecazlarla dolu cümleler yer almaktadır (Ö5). } \\
\text { Metinlerde anlamı bilinmeyen kelimelerin oranı bölgeden bölgeye farklılık } \\
\text { göstermektedir. Bu oran bazı yerlerde \%5 dolaylarında olabilir ama diğer } \\
\text { bölgeler için bu oran daha fazladır (Ö1;Ö2;Ö3;Ö5). }\end{array}$ \\
\hline & Etkinlikler & $\begin{array}{l}\text { Etkinlikler istenilen becerileri kazandırmada yetersiz ve birbirlerinin tekrarıdır. } \\
\text { Farklı beceriler için hep aynı etkinlikler tekrarlanmıştır (Ö1;Ö2). Etkinliklerde } \\
\text { dilin estetiğinden çok dilin dilbilgisel yönüyle ilgili çalışmalar vardır (Ö8). } \\
\text { Dilbilimsel yaklaşımlar temel alınmamıştır (Ö8). }\end{array}$ \\
\hline
\end{tabular}

Öğretmen görüşlerine göre ders kitaplarındaki metinler çocuğun ilgisini çekmekten yoksundur. Ayrıca metinlerde çevresel farklııklar dikkate alınmamakta ve metinler istenilen mesajı vermekte yetersiz kalmaktadır. Öğretmenlere derslerde uygun metinler kullanılabilecekleri esnekliği tanımakta ancak öğretmenler farklı bir metin bulmada ya da yeni bir metin oluşturmada yetersiz kalmaktadır. Çok güzel metinlerin yanında kalitesiz metinler de vardır. Edebiyatımızda şiir de dâhil olmak üzere çok güzel metinler vardır. Fakat ne yazık ki bunları kitaplarda göremiyoruz. Parçalar öğrencinin duyusal ve zihinsel seviyelerine uygun değildir. 5. sınıf kitabında yer alan metinlerin anlaşııması 6. sınıf kitabında yer alan metinlerin anlaşılmasından daha zordur. Metinlerde soyut ve mecaz kullanımlar çok fazladır. Metinlerde anlamı bilinmeyen kelimelerin çok fazla olmasına dikkat çekilmiş ve bu kelimelerin bölgeden bölgeye, okuldan okula da farklılık gösterdiği dile getirilmiştir. Buna bağlı olarak, metinlerin zorluk seviyesi artmakta ve öğrencilerin metinleri anlamaları zorlaşmaktadır. Öğrencinin, hayatı boyunca kullanmaya gerek duymayacağı arkaik/Osmanlıca sözcükler metinlerde yer almaktadır. Bu oran bazı okullarda \%5 dolaylarında olabilir ama diğer bölgeler için bu oran daha fazladır. Metinlerle birlikte verilen etkinlikler kazanımları vermede yetersiz 
ve birbirlerinin tekrarı niteliğindedir. Farklı beceriler için hep aynı etkinlikler tekrarlanmıştır. Etkinliklerde dilin estetiğinden çok dilin dilbilgisel yönüyle ilgili çalışmalar vardır.

Tablo 2. Öğrencinin ailesinden kaynaklanan problemler

\begin{tabular}{|c|c|c|}
\hline Tema & Alt Tema & Kodlar \\
\hline \multirow[t]{4}{*}{$\begin{array}{l}\text { Öğrencinin } \\
\text { ailesinden } \\
\text { kaynaklanan } \\
\text { problemler }\end{array}$} & $\begin{array}{l}\text { Sosyal } \\
\text { Durum ve } \\
\text { Statü }\end{array}$ & $\begin{array}{l}\text { Ailenin eğitim durumu önemlidir. Çünkü bilinçli bir aile çocuğun eğitimini } \\
\text { okula bırakmıyor, bu sürece dâhil oluyor (Ö1;Ö3;Ö4;Ö5; Ö6;Ö7). Ailede okul } \\
\text { okuyan yoksa ve aile okuryazar değilse öğrenci olumsuz etkileniyor } \\
\text { (Ö1;Ö3;Ö4;Ö5; Ö6). Çoğu ailenin okuma yazması yok. Aile kitap okumuyor. } \\
\text { Çocuğa olumsuz model oluyor (Ö2;Ö3;Ö4;Ö6;Ö8,Ö9,Ö10). Kendini iyi ifade } \\
\text { eden bir velinin çocuğu da kendini iyi ifade ediyor. Ailesinde doktor, avukat } \\
\text { vb. olan birinin dil becerisi de ailesinin eğitim durumu düşük olan } \\
\text { öğrencilere göre daha iyidir (Ö1;Ö2;Ö3;Ö5;Ö6). }\end{array}$ \\
\hline & $\begin{array}{l}\text { Ekonomik } \\
\text { Durum }\end{array}$ & $\begin{array}{l}\text { Ekonomik durumu iyi olan ailelerin çocuklarının dil becerileri de daha iyidir. } \\
\text { Ailenin ekonomik durumu yetersizse öğrenci istediği materyale ulaşamıyor. } \\
\text { Çocuk bir kitabı beğendiğinde alım gücü bulamıyor (Ö1;Ö2;Ö3;Ö5;Ö6). Bir } \\
\text { öğrencinin ders çalışacağı bir odası yoksa maddi şartları elverişli değilse, } \\
\text { öğrenci düzenli beslenemiyorsa bu onun hazır bulunuşluğunu olumsuz } \\
\text { etkiler (Ö1;Ö2;Ö3;Ö5;Ö6;Ö7). Ailenin ekonomik durumu önemli değil. } \\
\text { Ekonomik durumu kötü olan birçok çocuğun dil seviyesinin daha iyi } \\
\text { olduğunu da gördüm (Ö4). Ailelerin ekonomik durumlarının kötü olması } \\
\text { çocuğun dil becerisini kazanmasını olumsuz etkiliyor (Ö6). }\end{array}$ \\
\hline & İlgisizlik & $\begin{array}{l}\text { Ev de okul gibi bir eğitim yuvasıdır. Okulda öğrenilen bir konunun evde } \\
\text { tekrar edilmesi gerekir. Birçok veli bunun farkında değildir } \\
\text { (Ö1;Ö3;Ö4;Ö5;Ö6). Okuma yazması olan aileler de çocuklarıyla } \\
\text { ilgilenmiyorlar. Anne baba okumayınca çocuk okuma alışkanlığı } \\
\text { kazanamıyor. Ailenin rol model olması önemlidir (Ö1;Ö3;Ö4;Ö5;Ö6). Aileler } \\
\text { gelenekçi bir yapıya sahip oldukları için öğrencilerin yaratıcı olmalarına ve } \\
\text { dil becerilerini geliştirmelerine katkı sağlamamaktadırlar (Ö8). }\end{array}$ \\
\hline & İki Dillilik & $\begin{array}{l}\text { Çocuklar evde Kürtçe öğreniyorlar. \%90 dile Kürtçe başlıyor. Bu Türkçeyi } \\
\text { öğrenmeye ortaokulda da zorluk oluşturuyor (Ö4). Ana dili ile resmi dil } \\
\text { arasındaki farklılıklar sıkıntılara neden oluyor (Ö6;0̈7; Ö9; Ö10). }\end{array}$ \\
\hline
\end{tabular}

Öğretmenlerin çoğu, bilinçli ailelerin çocuğunun eğitimini okula bırakmadıklarını, bu sürece dâhil olduklarını, ailenin eğitim durumunun önemli olduğunu dile getirmişler. Öğretmenlerin yarısı, ailede okuyan yoksa ve aile okuryazar değilse öğrencinin bu durumdan olumsuz etkilendiğini belirtmişler. Öğretmenlerin büyük çoğunluğu, çoğu aile kitap okumadıkları için çocuğa olumsuz model olduklarını belirtmişler. Öğretmenlerin açıklamalarına göre, kendini iyi ifade eden bir velinin çocuğu da kendini iyi ifade ediyor. Ailesinde doktor, avukat vb. olan birinin dil becerisi, ailesinin eğitim durumu düşük olan öğrencilere göre daha iyidir. Çalışmaya katılan öğretmenlerden bazıları ailenin maddi durumunun iyi olmasının çocuğu olumlu etkilediğini, ailenin ekonomik durumunun kötü olması ise öğrenciyi olumsuz etkilediğini belirtirken bir öğretmen maddi durumun bir etkisinin olmadığını belirtmiştir. Ekonomik durumun yetersizliğinden dolayı öğrenci istediği materyali ve beğendiği kitabı almakta zorlanmaktadır. Bir öğrencinin ders çalışacağı bir odasının olmaması, maddi şartların elverişli olmaması en önemlisi de öğrencinin düzenli beslenememesi onun hazır bulunuşluğunu olumsuz etkilemektedir. Evlerin de okul gibi birer eğitim yuvası olduğunu ve okulda öğrenilen bir konunun evde tekrar edilmesi gerektiğini belirten öğretmenler, birçok velinin bunu ihmal ettiğini ileri 
sürmüşler. Okuma yazması olan aileler de çocuklarıyla ilgilenmiyorlar. Tabloya göre öğrencilerin \%90’ı evde Kürtçe konuştukları, Türkçeyi geç yaşta öğrendikleri, ana dili ile resmi dilin ayrı olması Türkçe öğrenmelerini olumsuz etkilemektedir.

Tablo 3. Okuldan kaynaklanan problemler

\begin{tabular}{|c|c|c|}
\hline Tema & Alt Tema & Kodlar \\
\hline \multirow[t]{3}{*}{$\begin{array}{l}\text { Okuldan } \\
\text { kaynaklanan } \\
\text { problemler }\end{array}$} & $\begin{array}{l}\text { Okul } \\
\text { Şartları }\end{array}$ & $\begin{array}{l}\text { Okulların ve sınıfların fiziki koşulları dil becerilerinin kazandırılmasında büyük } \\
\text { sorunlar oluşturmaktadır (Ö1;Ö2;Ö3;Ö4;Ö5;Ö6;Ö7;Ö9). Çoğu okulda } \\
\text { kütüphanenin sadece adı var çocuğa hitap etmiyor. Kütüphane yoksa dil } \\
\text { becerisi olumsuz etkileniyor. Kütüphanenin bulunması okuma becerilerinin } \\
\text { gelişmesinde önemlidir (Ö3; Ö6; Ö9; Ö10). Okulda bir okuma salonu yoksa } \\
\text { öğrenci boş anında rahat kitap okuyacak yer bulamaz (Ö3). Oyun sahnelenecek } \\
\text { mekânı, konuşma yapacağı yeri, panosu, kütüphanesi olan okullar dil becerisini } \\
\text { geliştirmede bir adım öndedir (Ö1;Ö2;Ö3;Ö4;Ö5). }\end{array}$ \\
\hline & $\begin{array}{l}\text { Sinıf } \\
\text { Mevcudu }\end{array}$ & $\begin{array}{l}\text { Sınıf mevcutlarının fazla olması öğrencilerin hepsine ulaşmayı engelliyor. } 40 \\
\text { dakikalık ders sürecinde hepsini konuşturmak ya da farklı etkinlikler yapmak } \\
\text { mümkün değil (Ö1;Ö2;Ö3;Ö4;Ö5;Ö6). Sınıf mevcutlarının fazla olması dil } \\
\text { becerilerinin öğrenilmesini olumsuz etkiliyor (Ö1;Ö2;Ö3;Ö4;Ö5; Ö6).Öğrenci } \\
\text { sayısı az olduğunda öğrenciye ulaşmak daha kolay olur } \\
\text { (Ö1;Ö2;Ö3;Ö4;Ö5;Ö9;Ö10). Sınıf mevcudu ne kadar az olursa o kadar etkili ve } \\
\text { verimli bir süreç yaşanır (Ö1;Ö2;Ö3;Ö4;Ö5). }\end{array}$ \\
\hline & Öğretmen & $\begin{array}{l}\text { Öğretmen değişiklikleri çok sık yaşanıyor. Her öğretmen değişiminde öğrencinin } \\
\text { öğretmene alışması öğretmenin öğrenciyi tanıması zaman alıyor. Öğretmen } \\
\text { değişimleri eğitim sürecini bir tanıma sürecine dönüştürüyor } \\
\text { (Ö1;Ö2;Ö3;Ö4;Ö5).Ayrıca Öğretmenin kullandığı dile, yönteme, tekniğe alışması } \\
\text { çocuk için zaman kaybı oluyor. Öğrenci öğretmene alışıyor. Bir bağ kuruluyor, } \\
\text { bir sonraki sene öğretmen değişince süreç başa dönüyor } \\
\text { (Ö1;Ö2;Ö3;Ö4;Ö5).Öğretmenlerin her açıdan iyi model olmaları gerekiyor (Ö4). } \\
\text { Öğretmenler arasında dil becerilerini kazandırma adına bir birlik } \\
\text { sağlanamamıştır (Ö7;Ö8). Bütün okulun katılım sağladığı münazara, forum gibi } \\
\text { etkinlikler yapılmamaktadır (Ö7;Ö10). }\end{array}$ \\
\hline
\end{tabular}

Çalışmaya katılan öğretmenlere göre okulların ve sınıfların fiziki koşulları dil becerilerinin kazandırılmasında büyük sorunlar oluşturmaktadır. Çoğu okulda kütüphaneler öğrenciye hitap etmekten uzaktır. Kütüphanelerin yokluğu dil becerilerini olumsuz etkilemektedir. Okulda bir okuma salonunun olması öğrencilerin, boş vakitlerinde kitap okumalarını kolaylaştıracaktır. Öğretmenlere göre oyun sahnelenecek mekânı, konuşma yapılacak yeri, panosu, kütüphanesi olan okullar dil becerilerini geliştirmede her zaman bir adım öndedir. Çalışmaya katılan öğretmenlere göre okullardaki öğrenci sayısı çok fazla dolayısıyla da sınıf mevcutları kalabalıktır. Bu durum, sınıftaki öğrencilerin tamamına ulaşmayı imkânsız kılmakta dolayısıyla öğrencilerin dil becerilerini edinmede sorunlar yaratmaktadır. Etkili ve verimli bir ders sürecinin gerçekleşmesi için sınıfların kalabalık olmaması gerekir. Neredeyse her yıl öğretmen değişiklikleri yaşanıyor. Bu da eğitim sürecini bir tanışma sürecine dönüştürüyor. Her öğretmen değişiminde öğretmenle öğrencinin tanışması karşııklı yeni bir tanışma sürecini başlatmaktadır. Öğrencinin, öğretmenin kullandığı dile, yönteme, tekniğe alışması zaman almaktadır. Öğretmenlerin her açıdan iyi model olmaları gerekiyor. 
Tablo 4. Diğer öğretim materyallerinden kaynaklanan problemler

\begin{tabular}{|l|l|l|}
\hline Tema & Alt Tema & Kodlar \\
\hline & & Materyalle ilgili problem olması için öncelikle materyalin olması lazım \\
Diğer öğretim & (Ö1). Birçok öğretmenin ders kitabı dışında materyali yoktur(Ö1). \\
materyallerinden & Etkinlikleri yapmada sınıf koşullarının çok da etkili olduğunu \\
kaynaklanan & düşünmüyorum (Ö2). Sınıfların akıllı tahtadan öte kitaplığa ihtiyacı var \\
problemler & (Ö3). Akıllı tahta var ama akılı tahtada internet yok (Ö8).
\end{tabular}

Öğretmenlerin açıklamalarına göre ders kitabı dışında kullanabilecekleri materyalleri sınırlıdır.

Son yıllarda etkileşimli tahtaların etkili olduğunu fakat bunları kullanabilecekleri sınıf ortamı ya da fiziksel koşulların olmadığına değinmişlerdir. Özellikle sınıf mevcutlarının fazla olması ve öğrenciler arasında seviye farkının belirgin olması farklı öğretim materyallerinin kullanımını sınırlandırmaktadır.

Tablo 5. Türkçe öğretimi programından kaynaklanan problemler

\begin{tabular}{|l|l|l|}
\hline Tema & Alt Tema & Kodlar \\
\hline $\begin{array}{l}\text { Türkçe öğretimi } \\
\text { programından } \\
\text { kaynaklanan } \\
\text { problemler }\end{array}$ & $\begin{array}{l}\text { Programda güzel yöntem ve teknikler var ancak onu kullanacak bir sınıf } \\
\text { ortamı yok (Ö1). Programın tek merkezden ya da tek elden yürütülmesi } \\
\text { sorundur (Ö2; Ö3; Ö6). Programın her yıl değişmesi hem öğretmen hem }\end{array}$ \\
& $\begin{array}{l}\text { öğrenci açısından sıkıntı yaratıyor (Ö3). Kazanımlar öğrencinin seviyesine } \\
\text { uygun değil. Bir kazanımı merkez bir okulda vermekle kırsalda vermek süresi } \\
\text { aynı değildir (Ö3). Programda bütünlük yok. 5. Sınıf 6, 7 ve 8'den tamamen } \\
\text { ayrı (Ö3; Ö4). Dilbilgisi öğretimi tam olarak yerleşmemiştir (Ö8). }\end{array}$ \\
\hline
\end{tabular}

Türkçe öğretmenlerinin görüşlerine göre müfredatın tek merkezden hazırlanması, bölgeler hatta okullar arasındaki farklııkların dikkate alınmaması karşılaşılan en önemli sorundur. Öğretmenler, müfredatta var olan kazanımları vermede sıkıntı yaşamaktadırlar. Tek elden hazırlanan müfredat bazı bölge ve okullarda öğrenciye istenen kazanımları verirken bazılarında yetersiz kalmaktadır. Programda öğretmenlere bir esneklik tanınmakta fakat sene sonunda yapılan sınavlar ve çocukların bu sınavlardan sorumlu olması nedeniyle bu esneklik uygulanamamaktadır. Müfredatın her yıl değişmesi öğretmenleri eğitim-öğretim sürecini öğrenmekten ziyade müfredatı öğrenmeye endekslemekte bu da eğitim sürecini olumsuz etkilemektedir. Öğretmenlerin müfredatla ilgili dile getirmiş oldukları diğer bir sorun ise müfredatta yer alan kazanımların yıllara eşit ayrılmamış olması ve 5 . Sınıfın 6, 7 ve 8 . Sınıftan çok bağımsız olmasıdır.

Tablo 6. Öğrencinin arkadaş çevresinden kaynaklanan problemler

\begin{tabular}{|l|l|l|}
\hline Tema & Alt Tema & Kodlar \\
\hline \multirow{2}{*}{$\begin{array}{l}\text { Öğrencinin arkadaş } \\
\text { çevresinden } \\
\text { kaynaklanan } \\
\text { problemler }\end{array}$} & $\begin{array}{l}\text { Çocuk zamanının çoğunu kitap okumakla değil de arkadaşıla geçiriyorsa } \\
\text { bu durum çocuğun sokak dilini öğrenmesine sebep oluyor (Ö1; Ö2, Ö3; } \\
\text { Ö6). Arkadaşlar birbirini etkiliyor. Arkadaş çevresinde kullandığı dil }\end{array}$ \\
& $\begin{array}{l}\text { standart Türkçeye uzak olduğu için dil becerisini olumsuz etkiliyor. } \\
\text { Nitekim Van'ın kendine mahsus bir ağzı var ve arkadaşları arasında bunu } \\
\text { konuşuyorlar (Ö3). Çocuk nasıl ki ailesinden etkileniyorsa arkadaşından } \\
\text { da öyle etkileniyor. Arkadaşının dil becerisi iyiyse kendisinin de iyi } \\
\text { oluyor. Arkadaşı okumuyorsa öğrenci okumaz (Ö3; Ö4). Arkadaşlar } \\
\text { arasında argo ve küfür kullanımının sıklığı öğrencinin dilin diğer } \\
\text { olanaklarını kullanmasını engellemektedir (Ö8). }\end{array}$ \\
\hline
\end{tabular}

Öğretmen görüşlerine göre çocuk zamanının çoğunu arkadaş çevresiyle geçirmekte bu da dil gelişimini doğal olarak etkilemektedir. Arkadaş çevresinin derse olan ilgisi, okumaya karşı tutumu 
öğrenci üzerinde etkili olmaktadır. Çevrenin kullanmış olduğu ağız özellikleri neyse öğrenciye de o yansımaktadır. Bu çoğu zaman standart Türkçeye uzak, sokağın dilinin veya yöresel dilin konuşulmasına sebep olmaktadır. Arkadaşlar arasında argo ve küfür kullanımının sıklığı öğrencinin dilin güzelliklerinin farkına varmasını engellemektedir.

Tablo 7. Öğrencinin ilgi, ihtiyaç, yetenek ve tutumundan kaynaklanan problemler

\begin{tabular}{|c|c|c|}
\hline Tema & Alt Tema & Kodlar \\
\hline $\begin{array}{l}\text { Öğrencinin ilgi, } \\
\text { ihtiyaç, yetenek ve } \\
\text { tutumundan } \\
\text { kaynaklanan } \\
\text { problemler }\end{array}$ & & $\begin{array}{l}\text { Okulda verilen seçmeli dersler öğrencinin ilgisinden çok okulun fiziksel } \\
\text { koşulları ve yeterlilikleri dikkate alınarak seçtiriliyor (Ö1). Okuldaki } \\
\text { seçmeli dersleri idareciler ve öğretmenler seçiyor. Bunun nedeni ise } \\
\text { koşullardır. Her seçmeli ders için öğretmen, sınıf ve malzeme lazım. } \\
\text { Bunları sağlamak zor (Ö2). Öğrenci dersi sevmediği zaman başarı } \\
\text { gelmiyor. Başarı için öğrencinin derse ilgi duyması önemlidir. Bu konuda } \\
\text { çocuğun ilgi ve ihtiyacı dikkate alınmıyor (Ö3; Ö6). Seçmeli dersler } \\
\text { önemli, diğer derslerde öğrencilerin ilgisine hitap eden etkinlikler } \\
\text { yapamazken seçmeli derslerde bunu daha rahat yapabiliyoruz (Ö4). } \\
\text { Okuma kitapları, anlaşılması zor hikâyelerden ibaret. Masal, efsane, çizgi } \\
\text { dizilere benzer kitapların okutulması hem kitap okumaya karşı ilgiyi } \\
\text { artıracaktır hem de kitap okumayı daha keyifli hale getirecektir (Ö5). }\end{array}$ \\
\hline
\end{tabular}

Öğretmenlere göre okullarda verilen seçmeli dersler öğrencinin ilgi ve ihtiyaçlarından çok

okulun fiziki koşulları ve yeterlilikleri dikkate alınarak seçtirilmektedir. Her seçmeli ders için öğretmen, sınıf ve malzeme gerektiği için idareciler ve öğretmenlerin belirlediği dersler seçilmektedir. Bu durum öğrencilerde dersle karşı ilgisizliğe neden olmaktadır. Öğrenci dersi benimsemediği için de başarısız olmaktadır. Öğretmenler, öğrencinin kendi isteğiyle seçtiği derslerdeki etkinliklerin daha keyifle işlendiğini dile getirmişler. Ayrıca öğrencilere okutulan kitaplardaki konuların ilgi çekici ve onların hoşuna gidiyor olması öğrencilerin dil becerilerine olumlu katkı sağlayacaktır. Masal, efsane ve çizgi dizilere benzer kitapların okutulması hem kitap okumaya karşı ilgiyi artıracaktır hem de kitap okumayı daha keyifli hale getirecektir.

\section{Tartışma ve Sonuç}

Görüşmeye katılan öğretmenler, tek elden hazırlanan müfredatın, hedef kitlenin tamamına hitap etmekten uzak olduğunu; müfredatın çok sık güncellendiğini, 5. sınıfın 6 , 7 ve 8. sınıflardan bağımsızmış gibi müfredatta bütünlüğün olmadığını ve kazanımların öğrencinin seviyesine uygun olmadığını dile getirmişler. Konuyla ilgili literatür incelendiğinde benzer eleştiriler başka çalışmalarda da karşımıza çıkmaktadır. Erdoğan ve Gök (2009) tarafından yapılan araştırmada katıımcıların kazanımlarla ilgili eleştirileri kazanım sayısının fazla olması ve dilbilgisi kazanımlarının ise yetersiz olmasıdır. Uygun ve Katrancı (2013)'nın yaptıkları çalışmada da kazanım sayısının fazla olması; bazı yöntem ve tekniklerin uygulanamaması, birtakım kavramların öğrenci seviyesinin üzerinde olması gibi sorunlara dikkat çekilmiştir. En dikkat çekici eleştiri ise Demir ve Yapıcı (2007)'dan gelmiştir. Yaptıkları çalışmada "Türkçe öğretimi programlarına konulan üst düzey hedeflerin, resmî dilin öğretiminde ve 
kullanımında hiçbir sorun yaşamayan gelişmiş ülkelerin müfredat programlarından Türkçeye transfer edilmiş gibi iğreti" durduğu vurgulanmaktadır.

Katılımcıların ders kitapları ile ilgili görüşleri, metinlerin çocuğun ilgisini çekmekten uzak olduğu; uzun metinlere ayrılan zamanın yetersiz olduğu ve metinlerin istenilen mesajı vermekte yetersiz kaldığı şeklindedir. Ayrıca metinlerde çevresel farklılıkların dikkate alınmadığı; metinlerde görsel öğelerin az, soyut ve mecaz kullanımların çok fazla olduğu; metinlerle birlikte verilen etkinliklerin, becerileri kazandırmada yetersiz kaldığı ve birbirlerinin tekrarı niteliğinde olduğu sonucuna varılmıştır. Konuyla ilgili yapılan çalışmalarda ders kitaplarına getirilen eleştirilerin yeni olmadığı öteden beri bu eksikliğin hissedildiği anlaşılmaktadır. Örneğin, Eren (1994) ve Kayman (1997) tarafından yapılan araştırmalar, öğretmenlerin 1981 Programına göre hazırlanan Türkçe ders kitaplarının, öğrenme-öğretme süreci, dil becerilerinin kazandırılması, metinle ilgili sorular ve alıştırmalar, görsel öğeler vb. bakımından Programın amaçlarına uygun olmadığını düşündüklerini ifade etmişlerdir. Alyılmaz (2010) da ders kitaplarındaki metinlerin öğrencilerin okuma isteğini azaltacak kadar uzun olmasından; çalışma kitaplarındaki etkinliklerin beceri alanlarına eşit dağılım göstermediğinden şikâyetçidir. Bölükbaşı ve Sarıbaş (2011)'ın yaptıkları araştırmada Türkçe ders kitaplarının öğrencilerin dikkatini çekmemesinden; konuların öğrenci seviyesine uygun olmamasından ve görseller ile metinler arasındaki ilişkinin zayıf olmasından yakınılmaktadır. Susar Kırmızı ve Akkaya (2009)'nın yaptıkları çalışmada bazı öğretmenler etkinliklerin fazla olduğundan ve sürenin yetmediğinden söz ederken bazı öğretmenler de etkinliklerin az olduğunu ve kendilerinin de yeni etkinlikler hazırlamadıklarını belirtmektedirler. Etkinliklere getirilen bu eleştiride Susar Kırmızı ve Akkaya yalnız değildir. Öztürk ve Karakoç (2008) da etkinliklerden yana zamanın darlı̆ı̆ndan veya etkinliklerin kalitesizliğinden şikâyet etmektedir. Hâlbuki içerik düzenleme yaklaşımı her zaman öğretmene ders kitabının içeriğini istedikleri gibi düzenleyebilecekleri imkânını vermektedir. Öğretmenler etkinlikleri azaltma ve yeni etkinlikler düzenleyebilme imkânına sahiptirler. Eğer bunu yapmıyorlarsa öğretmenlerin ya bu hakkı kullanmada imtina ettikleri veya Gün (2012)'ün de ifade ettiği gibi, programın kendilerine tanıdığı esnekliğin farkında olmadıkları anlaşılmaktadır. Çaylar (2008), çalışma kitaplarında yer alan alıştırmaların daha çok öğretmen merkezli etkinlikler olduğunu ileri sürerek aslında çoktan geride kalmış olması gereken bir iddiayı tekrar gündeme taşımıştır. Çünkü çalışma kitapları, Programın da yapısına uygun olarak öğrenciyi merkeze alan kitaplar iddiasıyla hazırlanmaktadır. Çaylar (2008)'ın diğer bir iddiası da etkinliklerin öğrencinin yaratıcılığını ortaya çıkarmaktan ziyade boşluk doldurma yapısına sahip olduğu yönündedir. Aynı şekilde Özatalay (2007) da ders kitaplarında öğrencilere kazandırılması hedeflenen becerilerle ilgili ifade ve etkinlik çalışmalarının ve yapılan yönlendirmelerin yetersiz olduğunu belirtmiştir. 
Görüşmeye katılan öğretmenlerin büyük çoğunluğu ders araç ve gereçleri konusunda ciddi eksikliklerin olduğunu; ders kitabı dışında herhangi bir materyallerinin olmadığını; sınıf ve okullarında kitap ve kitaplıkların bulunmadığını ifade etmişlerdir. Öğretmenlerin büyük çoğunluğu dinleme eğitiminin etkili olabilmesi için radyo, TV, teyp ve video gibi görsel işitsel araçlara yer verilmesinden yana olduklarını belirtmişlerdir. Literatürde yapılan farklı çalışmalarda da benzer sonuçlara ulaşılımıştır. Bu çalışmalarda, üzerinde ittifak edilen eksiklikler "araç-gereç"; "yardımcı kaynaklar"; "süreli yayınlar" ve "tv, teyp video vs." şeklinde sıralanabilir. Türkçe öğretimi ile ilgili yazılan kaynakların kuramsal boyutta kalması (Yanbıyık ve Yılmaz, 2016); gerekli araç-gerecin sağlanamaması (Erdoğan, Kayır, Kaplan, Aşık Ünal ve Akbunar, 2015); materyal kullanımı konusunda eksikliklerin olması (Susar Kırmızı ve Akkaya, 2009); Türkçe öğretimiyle ilgili yazılan kaynak kitapların kuramsal boyutta kalması ve büyük bölümünün çoklu ortam araç gereçleriyle desteklenmemiş olması (Alyılmaz, 2010); yardımcı kaynakların yeterli düzeyde olmaması (Uygun ve Katrancı, 2013) öğretim materyalleri için dile getirilen eleştirilerden birkaçıdır. Özbay (2000), ders kitabı dışındaki diğer yardımcı malzemeleri kullanan öğretmen oranının \%5,5 olduğunu belirtmektedir. Yalçın (1996) ise ders araç ve gereçlerinin sınırlı olması ve sağlıklı bir öğretmen eğitiminin olmaması yüzünden öğretmenlerin, derslerini büyük oranda ders kitaplarına bağlı kalarak anlattıklarını beyan etmektedir.

Her ne kadar ailenin ekonomik durumunun öğrencinin dil ediniminde belirleyici olmadığını söyleyen katılımcılar olsa da aslında bunun aksini ifade eden diğer katılımcıların söylemlerinden hareketle ailenin hem sosyal hem de ekonomik durumunun önemli ölçüde belirleyici bir role sahip olduğu anlaşılmaktadır. Özellikle kaynaklara ulaşmada ve ebeveynlerin okuryazar olmalarında sorun yaşandığını, bunun da öğrenciyi olumsuz etkilediğini belirtmektedirler. Ailenin rol model olması da önemli bir etkiye sahiptir. Çalışmamızın yapıldığı bölgeye benzer bir sosyo-ekonomik yapıya sahip olan Viranşehir'de yaptıkları çalışmada Aktürk ve Taş (2011), bölgede ailelerdeki çocuk sayısının fazla olması ve ailelerin, çocuklarıyla okul dışında yeterince ilgilenmemeleri ve çocuğun okulda aldığı bilgilerin evde tekrar edilmemesi gibi sebeplerin öğrencinin başarısını düşürdüğünü dile getirmişlerdir. Ereş ve Bıçak (2017) da ailenin, öğrencinin başarısını artıran önemli bir unsur olduğunu belirtmektedir. Benzer şekilde Demirel (2002) de ana dilini öğrenmenin, çocuğun, içinde yaşadığı ailede başladığını ifade etmektedir. Koçak, Ergin ve Yalçın (2014: 012), araştırmalarında, öğrenim düzeyi yüksek ebeveynlerin, kendi çocuklarının dil gelişiminde etkili oldukları sonucuna ulaşılımıştır.

Ailenin sosyoekonomik düzeyi çocuğun dil becerilerinin yanında, zekânın gelişiminde de önemli rol oynamaktadır. Diğer bir deyişle çocuğun, içinde bulunduğu sosyoekonomik düzeyin, sosyal, kültürel ve eğitim koşullarının, dil becerisini ve zekâ düzeyini etkilemesi söz konusudur. Kılıç ve Haşiloğlu (2017), öğrenci velilerinin gelir düzeyleri ile öğrencilerin Türkçe derslerindeki başarıları arasında doğrusal bir ilişki olduğunu; Çiftçi (2007) ise yaptığı çalışmada üst sosyoekonomik gruptaki 
çocukların, okuduğunu anlamada, alt sosyoekonomik gruptaki çocuklara göre daha başarılı olduğunu ortaya koymuştur. Günümüzde de ailenin ve toplumun sosyoekonomik düzeyinin, kültürel özelliklerinin ve yaşam biçiminin çocuğun dil gelişimi üzerinde etkili olduğu kabul edilmektedir. Çiftçi ve Temizyürek (2008)'e göre, çocuğun aile içinde yaşayacağı yaşantı zenginliği akademik başarılarının artmasına ve zihinsel faaliyetlerinin gelişimine kaynaklık edecektir. Zihin gelişiminin, kişinin geçirdiği yaşantılarla artabileceğini belirten Bacanlı (2000), gündelik hayatta çocuğuna oyuncak alan anne babanın ona yaşantı zenginliği sağlayacağı, böylece zihin gelişimine yardımcı olacağını dile getirmektedir (Akt. Çiftçi, 2007).

Ailenin ilgisizliği ve doğru model olmayışı öğrencinin başarısızlığına sebep oan başka bir unsurdur. Dolayısıyla ailede geçimsizlik ve iletişim bozukluğu gibi sorunlar öğrencilerin başarısını düşürmektedir (Şama ve Tarım, 2007). Gencer ve Çetin (2016), yaptıkları araştırmada ailenin destek ve ilgisinin öğrencilerin, ana dil öğreniminde akademik başarının artmasında önemli bir etkiye sahip olduğu sonucuna varmışlar. Ereş ve Bıçak (2017) da yetersiz ilginin öğrencilerin başarısız olmalarına yol açtığını; bu nedenle okul başarısından ailenin de sorumlu olduğunun ebeveynler tarafından bilinmesi gerektiğini dile getirmektedir. Aynı şekilde Alyılmaz (2010) da dil ediniminin okul öncesinde çocuğun ailesi ve yakın çevresiyle etkileşimi sonucunda başladığını ifade etmektedir.

Yukarıda belirtilen yakın çevre içinde çocuğun arkadaş çevresi de yer almaktadır. Katııımclara göre, çocuk zamanının çoğunu bu arkadaş çevresiyle geçirmektedir. Çocuk ailesinden etkilendiği gibi arkadaşlarından da etkilenmektedir. Arkadaşı okumuyorsa kendisi de okumaz. Arkadaşlarının kullandığı dilden etkilenen çocuk zamanla standart Türkçeye uzak, sokağın dilini konuşmaya başlar. Katılımcıların bu iddialarının aksine Ereş ve Bıçak (2017), yapmış olduğu çalışmada, toplumdaki “arkadaşlarından etkilenerek ders çalışmama inancı"nın geçerli olmadığını ileri sürmektedir.

Sınıfların kalabalık olması, okuma salonunun ve kütüphanenin olmaması ve sürekli öğretmen değişikliklerinin yaşanması dil edinimini olumsuz etkileyen unsurlar olarak katılımcılar tarafından ortaya konulmuştur. Ereş ve Bıçak (2017) da iyi olmayan okul şatlarının öğrencinin başarısını etkileyen önemli bir unsur olduğunu belirtmektedir. Erdoğan ve Gök (2009)'ün çalışmalarında, öğretmenler, fiziki şartların yeterli olmaması ve programda yer alan etkinlikleri uygulamak için uygun ortamın olmaması ile ilgili sorunlar yaşadıklarını tespit etmişler.

Katılımcıların önemli bir kısmı okulun fiziksel koşullarından, sınıfların kalabalık oluşundan ve öğretmenlerin kalıcı olmamasından yakınmaktadırlar. Okul şartlarının iyi olmaması özellikle sınıf mevcutlarının kalabalık olması öğrencilerin hepsine ulaşmayı zorlaşıyor. 40 dakikalık ders sürecinde hepsini konuşturmak ya da farklı etkinlikler yapmak imkânsızlaşıyor. Okulda bir okuma salonu yoksa öğrenci boş vakitlerinde rahat kitap okuyacak yer bulamaz. Literatürde de konuyla ilgili en fazla dile getirilen sorun sınıfların kalabalık oluşudur. Örneğin, Uygun ve Katrancı (2013), kalabalık sınıfların, 


\section{Öğretmen Görüşlerine Göre Türkçe Öğretiminde Karşılaşılan Problemlerin Kaynakları}

bazı etkinliklerin uygulanamamasına; Şahin, İnci, Turan ve Apak, (2006), alıştırma ve uygulama imkânlarının azalmasına; Aktürk ve Taş (2011), uygulama derslerinde çok fazla sorun yaşanmasına sebep olduğunu ifade etmekte ve öğrenci başarısının artması için sınıf mevcutlarının az sayıda olması gerektiğini dile getirmektedirler. Çünkü kalabalık sınıflarda öğretmenin öğrencilere ayırabildiği zaman azalmakta ve öğrenci merkezli eğitim güçleşmektedir.

Ereş ve Bıçak (2017)'a göre, öğrencilerin başarısını artıran en önemli unsur, okul ve haliyle okuldaki öğretmenlerdir. Öğretmenlerin bu kilit rolüne rağmen katılımcıların ifade ettiği gibi öğretmenlerin çok sık yer değiştirmeleri öğrenci ve öğretmen arasındaki paylaşımı azaltmakta; sürecin önemli bir kısmı yeni gelen öğretmenlerle öğrencilerin birbirlerini tanımakla geçmektedir.

Katılımcılarla yapılan görüşmede, okul koşullarının öğrencinin ilgi ve ihtiyaçlarını karşılayacak durumda olmadığı; özellikle seçmeli derslerin tercihi öğrencinin ilgi ve ihtiyaçlarına göre değil de koşullara göre idareciler tarafından yapıldığı; okulun fiziksel yeterlikleri öğrencinin ilgi, ihtiyaç ve yeteneklerinin önüne geçtiği sonucuna varılmıştır. Katılımcılar aynı zamanda başarı için öğrencinin ilgi ve ihtiyaçlarının önemine vurgu yapmışlardır. Öğrencinin ilgi, merak ve isteği, başarısını artırmaktadır (Altun, 2009). Öğrencinin bireysel özellikleri, zihinsel, fiziksel ve duygusal olgunluğu, uyum, kaygı ve motivasyon düzeyi okul başarısında etkili olmaktadır (Keskin ve Yapıcı, 2008; Akt. Ereş ve Bıçak, 2017).

\section{Kaynaklar}

Aktürk, Y. ve Mentiş Taş, A. (2011). illk okuma-yazma öğretiminde ses temelli cümle yönteminin uygulanmasına ilişkin öğretmen görüşleri, Adnan Menderes Üniversitesi Eğitim Fakültesi Eğitim Bilimleri Dergisi, 2 (1), 27-37.

Altun, S. (2009). Ilköğretim öğrencilerinin akademik başarısızlıklarına ilişkin veli, öğretmen ve öğrenci görüşlerinin incelenmesi, ilköğretim Online, 8(2), 567-586.

Alyılmaz, C. (2010). Türkçe öğretiminin sorunları, Turkish Studies, 5(3), 728-749.

Ayrancı, B. B. (2013). Öğrenci başarısını arttırmada okul müdüründen beklenen liderlik özellikleri, Anadolu Eğitim Liderliği ve Öğretim Dergisi, 1(2), 12-23.

Bölükbaşı, C. ve Sarıbaş, M. (2011). Illköğretim birinci kademe (1, 2, 3. sınıf) Türkçe öğretimi sorunları. Gazi Üniversitesi Türkçe Araştırmaları Akademik Öğrenci Dergisi, 1(1), 20- 26.

Çaylar, A. (2008). 1981 ve 2005 Türkçe öğretim programlarının (6 - 8. Sınıflar) karşılaştırmalı bir değerlendirmesi. Çanakkale Onsekiz Mart Üniversitesi Sosyal Bilimler Enstitüsü, Çanakkale: Yayımlanmamış Yüksek lisans Tezi.

Çeçen, M. A. ve Çiftçi, Ö. (2007). "ilköğretim 6. Sınıf Türkçe Ders Kitaplarında Yer Alan Metinlerin Tür ve Tema Açısından İncelenmesi." Milli Eğitim. Sayı: 173, s. 39-49.

Çiftçi, Ö. (2007), İlköğretim 5. Sınıf Öğrencilerinin Türkçe Öğretim Programında Belirtilen Okuduğunu Anlamayla Ilgili Kazanımlara Ulaşma Düzeyinin Belirlenmesi, Yayımlanmamış Doktora Tezi, Ankara: Gazi Üniversitesi Eğitim Bilimleri Enstitüsü

Çiftçi, Ö. ve Temizyürek, F. (2008). Illköğretim 5. Sınıf Öğrencilerinin Okuduğunu Anlama Becerilerinin Ölçülmesi, Mustafa Kemal Üniversitesi, Sosyal Bilimler Dergisi, 5(9), 109-128.

Demir C. ve Yapıcı, M. (2007). Anadili olarak Türkçenin öğretimi ve sorunları, Sosyal Bilimler Dergisi, C: IX, S: 2. 
Demirel, Ö. (2002), Türkçe öğretimi, PegemA yayıncılık, Ankara.

Er, O., Biçer, N. ve Bozkırlı, K. Ç. (2012). Yabancılara Türkçe öğretiminde karşılaşılan sorunların ilgili alan yazını ışığında değerlendirilmesi, Uluslararası Türkçe Edebiyat Kültür Eğitim Dergisi. 1/2, 51-69.

Erdoğan, M., Kayır, C. G., Kaplan, H., Aşık Ünal, Ü. Ö. ve Akbunar, ş. (2015). 2005 yılı ve sonrasında geliştirilen öğretim programları ile ilgili öğretmen görüşlerı: 2005-2011 yılları arasında yapılan araştırmaların içerik analizi, Kastamonu Ĕgitim Dergisi 171-196.

Erdoğan, T. ve Gök, B. (2009). Türkçenin Ana Dili Olarak Öğretiminde Karşılaşılan Sorunlar ve bu sorunların giderilmesine yönelik öneriler: Ankara örneği. Çukurova Üniversitesi Eğitim Fakültesi Dergisi, 3 (36), $1-16$.

Eren, K. S. (1994). Ilköğretim okullarında okutulan Türkçe ders kitaplarının program amaçlarına ulaşabilirlik düzeyi. Ankara: Ankara Üniv. Sosyal Bilimler Enstitüsü, Yayımlanmamış Yüksek Lisans Tezi.

Ereş F. ve Bıçak, D. K. (2017). Ortaokullarda öğrenci başarısını artıran ve engelleyen unsurlar, Akademik Sosyal Araştırmalar Dergisi, 51, 32-45

Gemalmaz, E. (2010), Türkçenin derin yapısı. C. Alyılmaz, O. Mert (Hzl.). Ankara: Belen Yayınları.

Gencer, K. ve Çetin, M. (2016). Illköğretim birinci kademe öğrencilerinin ana dil öğreniminde akademik başarılarına ailenin etkisi, Turkish Studies, 11/9, 441-460

Göçer, A. ve Moğul, S. (2011). Türkçenin yabancı dil olarak öğretimi ile ilgili çalışmalara genel bir bakış. Turkish Studies, 6/3, 797-810.

Gün, M. (2012). İlköğretim ikinci kademe Türkçe dersi okuma etkinliklerinde karşılaşılan sorunlar, Turkish Studies, 7/4, 1961-1977

Güneş, F. (2002). Ders Kitaplarının Incelenmesi, Ankara: Ocak Yayınları.

Kayman, F. (1997). Ortaokullarda Türkçe öğretiminde en çok kullanılan öğretim metotları ve bu metotların uygulanmasında karşılaşılan problemler (Ankara ilinde bir inceleme), Ankara: Gazi Üniv. Sosyal Bilimler Enstitüsü, Yayımlanmamış Yüksek Lisans Tezi.

Kılıç, Y. ve Haşiloğlu, M. A. (2017). Sosyoekonomik durumun öğrenci başarısına etkisi (7. Sınıf Türkçe ve fen bilimleri dersleri örneklemi), YYÜ Eğitim Fakültesi Dergisi, 14(1), 1025-1049

Susar Kırmızı, F. ve Akkaya, N. (2009). Türkçe öğretimi programında yaşanan sorunlara ilişkin öğretmen görüşleri, Pamukkale Üniversitesi Eğitim Fakültesi Dergisi. (1) 25. s.42-54.

Koçak, N., Ergin, B. ve Yalçın, H. (2014). 60-72 aylık çocukların Türkçe dil kullanımı düzeyleri ve etki eden faktörlerin incelenmesi. MKÜ Sosyal ve Ekonomik Araştırmalar Dergisi, 16(2), 100-106.

Özatalay, H. (2007). IIlköğretim 1. Kademe Türkçe öğretim programında öğrencilere kazandırılması hedeflenen temel becerilerin ders kitaplarında kullanılmasına ilişkin durum çalışması. Marmara Üniversitesi Eğitim Bilimleri Enstitüsü İlköğretim Anabilim Dalı Sınıf Öğretmenliği Bilim Dalı, İstanbul: Yayımlanmamış Doktora Tezi.

Özbay, M. (2000). Öğretmen görüşlerine göre Ankara merkez ilköğretim okullarında Türkçe öğretimi. Ankara.

Özbay, M. (2003). Türkçe öğretiminde hedef-araç ilişkisinin ders kitabı örneğinde değerlendirilmesi, TÜBAR-XIII. 59-69

Öztürk-Karakoç, B. (2008). Illköğretim 6. Sınıf Türkçe dersi öğretim programı okuma alanının öğretmen görüşlerine göre değerlendirilmesi. Çukurova Üniversitesi Sosyal Bilimler Enstitüsü İlköğretim Ana Bilim Dalı, Adana: Yayımlanmamış Yüksek Lisans Tezi.

Sever, S. (2003). Çocuk ve edebiyat, Ankara: Kök Yayıncılık 
Şahin, İ., İnci, S., Turan, H. ve Apak, Ö. (2006). İlk okuma-yazma öğretiminde ses temelli cümle yöntemi ile çözümleme yönteminin karşılaştırılması, Milli Eğitim Dergisi, 171, 109-129.

Şama, E. ve Tarım, K. (2007). Öğretmenlerin başarısız olarak algıladıkları öğrencilere yönelik tutum ve davranışları, Türk Eğitim Bilimleri Dergisi, 5(1), 135-154.

Uygun, M. ve Katrancı, M. (2013). Sınıf öğretmenlerinin Türkçe derslerinde karşılaştıkları sorunlara ilişkin görüşleri, Çankırı Karatekin Üniversitesi Sosyal Bilimler Enstitüsü Dergisi 4(1), 255-270

Yalçın, A. (1996). Türkçe ders kitaplarının plânlanması ve yazılması, Türk Yurdu, 107, 24-27.

Yanbıyık, S. ve Yılmaz, F. (2016). Literatür temelli bir araştırma: Türkçe öğretiminin sorunları, Journal of Research in Education and Society, 20, 16, 3(1), 60-75

Yıldırım, A. ve Şimşek, H. (2008). Sosyal bilimlerde nitel araştırma yöntemleri. Ankara: Seçkin Yayıncılık

Güneş, D.Z. ve Kara, S.B.K. (2016). İlkokulların sorunlarının öğretmenler kurulu toplantılarına dayalı olarak incelenmesi. Bartın Üniversitesi Eğitim Fakültesi Dergisi, 5 (1), 142-153.

\section{Extended Abstract Introduction}

Environmental factors are primarily effective in the acquisition of the basic language skills of Turkish. According to Alyılmaz (2010), language acquisition starts with the interaction of the child with his/her immediate environment, family before school. Although the acquisition of language begins with communication with the immediate environment, the learning and development of literacy skills through the effective and correct use of language necessitates instruction at school or other educational institutions as it requires deliberate study. Özbay (2003) states that the main aim of Turkish education which affects the acquisition of knowledge, skills and behaviors is to educate individuals who use their mother tongue which is the bearing element of culture well and correctly. There are many factors that make the process of realizing the main purpose which Özbay draws attention to. In this study, the aim was to identify the factors that negatively affected the teaching of Turkish using the opinions of the teachers.

Method

This study which aims to reveal the source of the problems encountered in Turkish teaching was designed in the qualitative research tradition. The nested case study model was used in the study because the family, school and education environments and their relation to the program portrayed an intertwined situation. The participants of the study consisted of 10 Turkish teachers who had served at least 5 years in three schools in İpekyolu, Tuşba and Edremit districts of Van. The semi-structured interview form developed by the researchers was used for data collection. The semi-structured interview form consisted of 7 questions. The interviews were conducted in accordance with the essence of the semi-structured interview technique; theme and sub-themes were formed based on the interview questions. Teacher opinions were categorized according to the appropriate theme and sub theme.

\section{Result and Discussion}

The teachers stated that the texts in the textbooks were far from attracting the attention of the children and were inadequate in giving the desired message; environmental differences were not considered in the texts; the visual elements in the texts were too few, abstract and metaphorical usage was high. The teachers also stated that the activities given with the texts were insufficient to help the students gain skills and they were repetitive of each other. The majority of the teachers who participated in the interviews stated that there were serious shortcomings in the course materials; there were no other materials other than the textbooks; and in their classrooms and schools, there were no books and libraries. $80 \%$ of the teachers stated that they were in favor of listening to audio-visual tools such as radio, TV, tape and video in order to be effective in listening education. Although there were teachers who stated that the economic status of the family wasn't decisive in students' language acquisition, there were opposite views which stated that the social and economic status of the family had a significant role. Teachers stated that there was a problem especially in accessing resources and parents' not being literate which affected the students negatively. A significant number of the participants complained about the physical conditions of the school and crowded classes. During the interviews with the participants, it was found that the school conditions were not sufficient to meet the needs and interests of the students, especially the choosing of elective courses was not done according to the students' interests and needs. The choices were shaped by the administrators. It was concluded that the schools' physical features were considered more important than the students' interests, needs and abilities. 
In the literature, these problems are encountered in many studies. Alyılmaz (2010) states that the texts in the textbooks are long enough to reduce the students' desire to read and complains that activities don't show equal distribution of skills. Çaylar (2008) argues that activities have a gap filling structure rather than revealing the productivity of the student. Kılıç and Haşiloğlu (2017) state that there was a linear relationship between the income levels of the students' parents and their achievement in Turkish courses. Uygun and Katrancı (2013) state that crowded classes were not able to allow the implementation of some activities. Şahin, Inci, Turan and Apak (2006) suggest that the reduction of exercise and application possibilities. Aktürk and Taş (2011) state that there are a lot of problems in the implementation of the courses and they state that class sizes should be small in order for student success to increase. 